\title{
The Russian Far East and Russian Security Policy in the Asia-Pacific Region
}

\section{Malin Østevik and Natasha Kubrt}

Abstract This chapter examines the place of the Russian Far East in Moscow's security-policy deliberations. Analysing influences ranging from the deployment of Russian armed forces in the Far East to bilateral and multilateral engagements in the Asia-Pacific, and Russian-Chinese attempts at coordination in global politics, the authors find that factors local to the Russian Far East are particularly salient for understanding Russian security policy in the Asia-Pacific. The asymmetry between Russia's underdeveloped Far Eastern region and the populous and economically thriving countries of the Asia-Pacific region represents a significant vulnerability for Russia. Security concerns related to the social and economic underdevelopment of the Russian Far East have thus prevented the 'pivot' from being grounded in broad regional engagement.

Keywords Security $\bullet$ Russian Far East $\bullet$ Asia-Pacific region $\bullet$ Military policy $\bullet$ Securitization

\section{M. Østevik ( $\square)$}

Research Group on Russia, Eurasia and the Arctic, Norwegian Institute of International Affairs, Oslo, Norway

N. Kuhrt

Department of War Studies, King's College, London, UK

(C) The Author(s) 2018

H. Blakkisrud, E. Wilson Rowe (eds.), Russia's Turn to the East,

Global Reordering, https://doi.org/10.1007/978-3-319-69790-1_5 
Security concerns are a central aspect of the Russian 'pivot to the East': Moscow's security policy towards the wider Asia-Pacific region is closely linked with the status of the Russian Far East as both a frontier and a gateway region. Since the breakdown in Russian relations with the West in the aftermath of the 2014 annexation of Crimea, steps have been taken towards integrating the Russian Far East into Asia-Pacific economic networks. The current crisis has undoubtedly added a sense of urgency to Moscow's policies of reorienting towards the Asia-Pacific region. But to just what extent can recent changes and initiatives be attributed to the deteriorating relationship between Western countries and Russia? Has a fundamental shift taken place-or is this simply an acceleration of processes already well underway before 2014?

In this chapter we survey recent developments in the Kremlin's security policy in the Russian Far East and towards the Asia-Pacific region. First, we establish a baseline by exploring the main policy tenets since the onset of Russia's current 'pivot to the East', which commenced around 2012. Here we map out issues of contention, areas of cooperation and important bilateral and multilateral relationships in the broader region. We then look for significant changes in these patterns since 2014 .

The focus is on state-level security policy, but 'security' is understood here across a broad spectrum of national, international, central and local factors. Beyond hard security, we pay particular attention to economics, a field that has become increasingly securitized in Russia in recent years (Connolly 2016). We also examine various security-policy influences, ranging from the deployment of Russian armed forces in the Far East to bilateral and multilateral engagements in the Asia-Pacific region, and Russian-Chinese attempts at coordination in global politics. But first, a few words on the historical background.

\section{Historical Backdrop to Russia’s Security Policy IN THE ASIA-PACIFIC}

With the break-up of the Soviet Union, Russia revived relations with key countries of East Asia, hereunder its three immediate neighbours in the Russian Far East: China, Japan and the Democratic People's Republic of Korea (DPRK). Already in December 1991, Russia resumed diplomatic relations with China, and these were strengthened throughout the Yeltsin presidency (Kuhrt 2007, pp.10, 45). The focus on China was due primar- 
ily to the pressing need for border demarcation, a process that had begun already in 1989. After this process was concluded in 2004, the strategic partnership between China and Russia picked up speed.

In the early 1990s, it was Japan that, due to its economic strength and Western outlook, was seen as the most important player in the Asia-Pacific. However, Russia's territorial dispute with Japan over the Kuril Islands persisted, impeding any significant improvement of Russo-Japanese relations in the 1990s and early 2000s (Kuhrt 2007, p.99).

Russia also shares a $17 \mathrm{~km}$ long land border with the DPRK. Soviet relations with the DPRK had started to deteriorate already during the Gorbachev presidency, and continued to worsen during the 1990s. Under Putin's presidency, relations were revived, and in 2003 Russia became a party to the Six-Party Talks on DPRK's nuclear programme. DPRKRussian relations have since experienced peaks and low points, but the ascendancy of Kim Jong-un in 2012 brought relations to a standstill (Shin 2014, pp.133-35).

\section{Russian Security Policy in the Asia-Pacific Region: 2012-14}

Throughout history, Russia has attempted various 'pivots' to the East. The most recent one entered the public debate as 'the turn to the East' (povorot na vostok) in the latter part of the first decade of the new millennium (Lukianov 2010; Karaganov 2014). This 'pivot' has three main parts: a programme for the socioeconomic development of the Russian Far East, efforts towards economic integration into the Asia-Pacific region and strategic bilateral and multilateral political engagement in the region (Fortescue 2016, p.423). All three parts play into each other, but the third one is in focus here.

With its harsh climate and shortage of human capital, the Russian Far East has lagged behind European Russia, not to say its Northeast Asian neighbours, in socioeconomic development (see Vakulchuk, Chap. 8, this volume). This is seen as a national security concern. To address this, Russian authorities undertook a new political push towards developing the Russian Far East from around 2012. That year the Ministry for the Development of the Far East was set up at the federal level, headed by Viktor Ishaev, former governor of Khabarovsk Krai and, since 2009, Presidential Plenipotentiary to the Far Eastern Federal Okrug (see Blakkisrud, Chap. 2, this volume). 
Before being replaced in 2013, Ishaev announced a comprehensive programme for the economic and social development of the Far East and Baikal region. While the programme was concerned primarily with the economic and social dimensions of development, the overarching context was framed in terms of security. The Russian Far East was said to occupy 'a favourable economic and geographical position in the (...) Asia-Pacific region', as 'the ratio of the major economic power centres of the world economy is changing quite rapidly in favour of the Asia-Pacific region'. Hence, the 'welfare of the whole country' depended on the government's ability to solve the 'geopolitical, strategic, economic and demographic problems' of the Russian Far East (Pravitel'stvo Rossiiskoi Federatsii 2013).

The programme thus illustrates how the economic and social development of the region was securitized and treated as inherently interlinked with regional security concerns in the Asia-Pacific region. However, such interlinkage was nothing new. While still head of Khabarovsk Krai, Ishaev had drawn attention to the plight of the region in a plan for regional development that warned of the Russian Far East becoming a double periphery, isolated from European Russia as well as from the Asia-Pacific region, should Moscow fail to develop it (see Kuhrt 2012).

The external trigger of Russian foreign policy's 'turn to the East' was the realization, demonstrated by the 2008 financial crisis in the West and the relative robustness of the Asia-Pacific region by contrast, that the latter was indeed becoming a global centre of power. While this realization concerned the increased influence of Asia-Pacific states in global economic terms specifically, it also had geopolitical and security implications. According to the 2013 Foreign Policy Concept: 'The current stage of the world development is characterized by profound changes in the geopolitical landscape largely provoked or accelerated by the global financial and economic crisis' (Ministry of Foreign Affairs 2013). With territories bordering on China, Japan and the Korean peninsula, Russia was, at least from its own perspective, in a geopolitical position to claim a more substantial role in regional Asia-Pacific affairs.

To explore the security-related aspect of Russia's 'turn to the East' prior to 2014, we begin by assessing Russia's strategic partnership with China and the Eastern border as a driver of insecurity. We then turn to military deployment in the Russian Far East, bilateral relations with Japan, the US alliance system in the Asia-Pacific and Russian multilateral engagements in the region. 


\section{Strategic Partnership with China}

The Sino-Russian strategic partnership is central for understanding Moscow's security policy in Northeast Asia. In the autumn of 2004, agreement was finally reached on a treaty to demarcate the border between Russia and China (Kuhrt 2007, p.116). On the Russian side, there were some grievances concerning concessions made to the Chinese, particularly among local Russian residents, but, in general, the agreement represented significant progress and provided a basis for a maturing of state-level relations between the two countries. The settlement of territorial claims served to defuse lingering tensions, so that the two sides could move on to tackling other practical security and economic issues of a less principled character.

Joint military exercises can function as an indicator of the actual level of trust between countries, in terms of security. The first such joint exercise between Russia and China-Peace Mission-2005 (Mirnaia missiia2005) — was held already in the autumn of 2005, only one year after settlement of the border dispute (Pulin 2005). These 'peace mission' exercises continued to be held, generally every second year, interchangeably as bilateral exercises between Russia and China and multilateral exercises within the framework of the Shanghai Cooperation Organization. In 2012, Russian-Chinese joint naval exercises were added to the portfolio. The exercise scenarios have mostly focused on anti-terrorism and counterpiracy, but the number of troops involved has been very high and both sides have contributed advanced equipment. The conduct of such joint exercises has thus been a way of signalling a commitment to defence cooperation (Weitz 2015).

Still, despite the improving situation, scholars have noted that the SinoRussian strategic partnership is far from turning into an alliance (Bolt and Cross 2010; Weitz 2012). In 2008, Bobo Lo coined the term 'axis of convenience', arguing that, although the two countries cooperated on several issues, the collaboration was mostly grounded in tactical concerns and lacked a strategic underpinning. This stemmed from fundamental differences in national interests and outlook (Lo 2008). While some Western analysts and unofficial Chinese voices (Gelb and Simes 2013; Goldstein 2017; Stokes 2017) now suggest that an alliance is in the making, this seems to be an unlikely outcome (Wishnick 2017). It is true that the strategic partnership is increasingly based on a shared agenda and that there is a significant alignment. However, this is a 'soft alliance'. There is no significant military component (Gabuev 2015), and the disparity in economic 
status continues to be unpalatable to the Russians. Despite the Sinocentric nature of Russia's Asia policy, Russia aspires to engage other Asian partners, and an alliance with China would complicate such engagement. Moreover, China has traditionally eschewed alliances of any kind (Wishnick 2017).

\section{The Russo-Chinese Border as a Source of Insecurity}

Russia has a $4209 \mathrm{~km}$ long border with China. Understanding the implications of this from a symbolic and practical perspective is essential for uncovering the local- and regional-level insecurities that drive Russian security policy in the Far East. The border and its adjacent regions constitute an important source of Russian vulnerability, primarily vis-à-vis China. Cross-border trade and engagement have highlighted the asymmetry between Russia's underdeveloped and underpopulated eastern regions, and the economically thriving and densely populated Chinese territory on the other side.

The insecurity associated with the border region can easily be identified in official discourse, such as in the 2009 National Security Strategy (Rossiiskaia gazeta 2009). Informally, there has at times been 'widespread suspicion of Chinese activity in the Russian Far East and resentment of China's economic power' in the Russian Ministry of Foreign Affairs (Kuhrt 2012, p.477). In the public discourse, old fears of uncontrolled Chinese immigration frequently resurface (see Lenta.ru 2015). Such anxieties are, according to Viktor Larin, 'informed to a great extent by perceptions of illegality and fears of Chinese expansion' (Larin 2012, p.70). This was despite the fact that net Chinese immigration with the goal of permanent residence declined from 2001 to 2008 (Larin 2008, pp.148-49). According to the Federal State Statistic Service, between 2008 and 2012, fewer than 2000 Chinese immigrated to Russia yearly for permanent residence. ${ }^{1}$ Likewise, trade asymmetries have been a concern-some regions that adjoin China, for example Amur Oblast, are reported to rely on China for nearly 90 per cent of their trade (RIA Novosti 2015b).

For these reasons, the high-priority issue of developing the Russian Far East has become securitized and fraught with ambivalence. However, it is also recognized that achieving this long-sought social and economic development will necessitate Chinese and other East Asian economic involvement, not least in investments and financing (Kremlin.ru 2013, see also Blakkisrud, Chap. 2, this volume). To mitigate the insecurity that 
accompanies initiatives aimed at greater investment, Russian policymakers have sought to integrate the Russian Far East into East Asian networks, while simultaneously deepening the region's integration with European Russia (Kuhrt 2012).

\section{Deployment of Armed Forces in the Russian Far East}

Security concerns associated with regional integration are also evident in the military posturing in the Eastern Military District (EMD), which includes the Pacific Fleet. The EMD was established in 2010 as part of a reform of the command structure through a merger of the Far Eastern Military District and the eastern parts of the Siberian Military District. With the merger, the entire Chinese border area, except for the short, mountainous and inaccessible stretch west of Mongolia, was covered by one military district. Indeed, a decisive factor behind the restructuring was probably the wish for more effective control over the Far Eastern border region (Hyodo 2014, p.47). Accompanying the structural reform of the Russian armed forces was the State Armament Programme 2020, likewise adopted in 2010. Although it is difficult to assess the relative prioritization of the EMD within this programme, it is clear that the EMD has seen significant improvement in firepower and equipment more broadly (see below for more detail).

Defence capacity against a possible Chinese ground-force invasion is an important factor in the dimensioning of the EMD: Whereas the three other military districts in Russia have two armies each, the EMD has four. They are all stationed along the country's perimeters, and the two stationed on the border with China are unusually large in terms of troop numbers (Carlsson et al. 2013, p.52). That the Russian armed forces are deploying on the basis of a scenario involving a potential conflict with China is hardly surprising: contingency planning is a military responsibility. Nonetheless, it is a further indication that the Sino-Russian partnership remains fraught with tensions and insecurities.

\section{Bilateral Relations with Japan}

The main feature of Russo-Japanese bilateral relations remains the border dispute over the Kuril Islands. ${ }^{2}$ Despite increases in Russo-Japanese trade, the dispute has long obstructed the development of mutual trust at the political level. Moreover, in recent years, with the evolving regional power 
dynamics in the Asia-Pacific region, the military-strategic importance of the Kuril Islands appears to have grown for Moscow-as signalled by then-President Dmitrii Medvedev's visit to the islands in 2010 and the beefing-up of military infrastructure there. However, Tokyo has interpreted the increased strategic emphasis as directed primarily at balancing China; although it monitored military activity closely, Japan also seized the opportunity to build stronger military-to-military ties with the Russian armed forces (Tabata 2012; Pajon 2013).

When Putin returned to the presidency in 2012, he signalled willingness to negotiate on the border issue, should Japan be willing to compromise (Akaha 2012). In March 2013, it was agreed to reopen peace talks between the two countries, and in April that year, Shinzo Abe visited Moscow, as the first Japanese prime minister to do so for more than ten years (Chotani 2015). The two countries also agreed on a $2+2$ dialogue mechanism involving the defence and foreign ministers of both states (Pajon 2013). These meetings indicated a push for improvement of RussoJapanese relations. Significant areas of contention nonetheless remained, with Russia being particularly hostile to the development of a joint Japanese-US anti-missile system (Blank 2014).

\section{US-led Alliances in Northeast Asia}

Following the US 'pivot', or rebalancing, to Asia announced in late 2011, Washington took a more proactive stance in the Asia-Pacific region. The major objective of the US approach was 'to dissuade China from making a bid for hegemony' and to sustain its own strategic predominance in the Asia-Pacific region (Silove 2016, p.46). Two important aspects of this new approach were the further development of bilateral security alliances with Japan and South Korea and the engagement with Southeast Asian states (Friedberg 2015; Green 2016). This, together with the more assertive US military presence in Northeast Asia, including its missile defence system and strategic nuclear forces, sparked Chinese fears of encirclement (Xiang 2012).

The dynamic precipitated by the increased US involvement in the AsiaPacific reactivated latent conflicts, like the one in the South China Sea (Kireeva 2014, p.37). Moscow viewed the intensified US engagement in the region with caution and ambivalence, partly because Russia itself enjoyed limited leverage in East Asia and remained dependent upon China in regional political affairs. Moscow was, however, not as critical of the US 
presence in East Asia as China. Some Russian scholars even called for the possibility of East Asia becoming an arena for a Russian-US détente (Lukin 2012). Officially, however, the Kremlin in its 2013 Foreign Policy Concept in the section on the Asia-Pacific warned that US attempts at 'preserv[ing] their traditional positions' was causing 'instability in international relations' (Ministry of Foreign Affairs 2013).

\section{Russia's Approach to Multilateralism}

East Asia as a region is above all characterized by its advanced economic networks. Russia's engagement has traditionally relied on bilateral relations - with China in particular. By dealing with countries on a bilateral basis, Russia remains outside regional trade agreements and, to some extent, regional networks. This has hampered the political leverage that greater economic engagement and diplomatic investment could otherwise bring (Karaganov 2012; Kuhrt 2014, p.141). And this is why Russia has in recent years increasingly begun to participate in East Asian multilateral forums, signalled above all by Russia's hosting of the 2012 Asia-Pacific Economic Cooperation (APEC) summit in Vladivostok (Koldunova 2016, pp.533-34).

Russia became a member of APEC already in 1997 and had joined the Asian Regional Forum (AFR) even earlier, in 1994. In 2010, Russia joined the Asia-Europe Meeting (ASEM) and, in 2011, the East Asia Summit (EAS), and Moscow had signed several treaties aimed at facilitating cooperation between ASEAN and Russia. In particular, the EAS is relevant for security issues. In 2013 Russia used this forum to call-with the support of China and Brunei-for a new regional security architecture in East Asia (Shestakov 2013). With its emphasis on a non-bloc approach to regional security, the proposal was clearly formulated as a reaction against the US-sponsored 'hub and spokes' system of alliances in the Asia-Pacific region.

However, by the time of the Ukrainian crisis, the success of the various multilateral efforts was still limited: few significant steps towards economic integration had been taken. Although engagement with the region increased, this was still secondary to bilateral engagement. The main strategic direction of Russia's policy in East Asia remained its partnership with China. Russian academics have blamed the Russian Ministry of Foreign Affairs and called for a more comprehensive approach which would include actors from sectors such as private business, academia and civil society 
(Koldunova 2016, pp.540-46). There have also been calls for a true willingness to reform, in a manner that could facilitate integration into the East Asian economic networks (Baev 2016, p.94).

\section{The 2014 Crisis With the West and Russia's Northeast Asian Security Policy}

Has anything changed in Russia's security policy or actions in East Asia in light of the crisis with the West? Some scholars have indicated that the 2014 crisis and Russia's subsequent relative isolation may have triggered an intensification of the foreign policy 'turn to the East' (Kireeva 2014, p.48; Baev 2016, p.90). We will assess the plausibility of this claim against the baseline established above.

The most tangible effects of the war in Ukraine and subsequent Western sanctions on Russian security policy in East Asia concern the practical consequences for the Russian military in the Far East. As noted, the EMD includes the Pacific Fleet. A significant share of the State Armament Programme 2020 was earmarked for improvement of naval capabilities. And it was precisely this capability development that was hit the hardest by the sanctions and by Ukraine's freeze of military exports to Russia. The two Mistral amphibious assault ships that had been purchased from France, and that fell victim to the sanctions, were meant for the Pacific Fleet. Likewise, construction of several types of vessels has been severely delayed due to the unavailability of parts from Germany and Ukraine (Cooper 2016, p.49).

Other procurements under the armaments programme have proceeded according to plan. For example, the EMD troops have had their firepower significantly strengthened, as they have been re-equipped with new Iskander-M ballistic and cruise missile systems (RIA Novosti 2015a). In 2015 and 2016, Russia also deployed S-400 surface-to-air missile defence systems along its eastern coast to 'protect the sky over the main bases of the Pacific Fleet' against US missile systems and aircraft (RIA Novosti 2016; see also Plopsky 2016). However, the decision to deploy Iskander-M missile systems in the Far East had been announced already in 2011 (RIA Novosti 2011). Thus, their deployment shows that the decision to strengthen Russia's military posture in Northeast Asia had been taken long before the 2014 crisis. 
Since 2014, official Russian statements praising the strategic partnership with China have proliferated. In an interview with a Chinese news agency, Putin even stated that bilateral relations had advanced so far that Russian experts 'have had trouble defining today's general state of our common affairs' (Kremlin.ru 2016a). The rhetoric of public statements resonates with doctrinal-level statements. The 2013 version of the Russian Foreign Policy Concept was the first to define Russia's perspective on East Asia in direct relation to the dwindling role of the West in world affairs: 'The ability of the West to dominate world economy and politics continues to diminish. The global power and development potential is now more dispersed and is shifting to the East, primarily to the Asia-Pacific region' (Ministry of Foreign Affairs 2013). Similar statements are found in the 2016 version, where the Asia-Pacific enjoys a far more prominent role than in previous versions (Ministry of Foreign Affairs 2016).

That international-level concerns are among the main political drivers behind the Sino-Russian partnership is already well established. In early 2014, Russian Foreign Minister Sergei Lavrov went so far as to state that international cooperation was the most important element of the bilateral relationship (Ministry of Foreign Affairs 2014). To the extent that this holds true, we could expect the breakdown in Russia's relations with the West would lead to further coordination with China on internationallevel issues. And, indeed, this is what has been happening. The two countries have had an unusually high number of top-level meetings since 2014; according to the Chairman of the Standing Committee of the Chinese National People's Congress Zhang Dejiang, Putin is the state leader with whom the Chinese president has met the most often (Kremlin. ru 2016b).

In the UN Security Council (UNSC), the two countries have been said to form a bloc with regard to the search for an international solution to the Syrian conflict: altogether five resolutions have been vetoed by both countries. Still, while both Russia and China refer to concerns related to the territorial sovereignty of the Syrian state, their approaches appear to diverge. In October 2016, China abstained for the first time from voting on a UNSC resolution on Syria that Russia vetoed. Afterwards, China stated that it was important to find a solution to the conflict, but, since key concerns of some Council members had not been taken into consideration, it had to abstain (Permanent Mission of the People's Republic of China to the UN 2016). By contrast, Russian ambassador Vitalii Churkin indicated that Western UNSC members wanted to 'destroy' Syria, as they 
had done with Libya (United Nations 2016). This seems to validate Aglaya Snetkov and Marc Lanteigne's labelling of Russia as 'the loud dissenter' and China as 'the cautious partner' (Snetkov and Lanteigne 2015).

Chinese dissatisfaction with what it perceives as Russia's exaggerated anti-Western attitudes-aggravated by the 2014 crisis-is precisely one of the reasons why Pavel Baev (2016, p.91) argued that, as of late 2015, attempts to strengthen Sino-Russian ties had failed. Baev is correct in noting that these relations do not make for any 'super-partnership' (Baev 2016, p.91). Indeed, the bilateral relationship does appear rather similar to what it was before 2014: somewhat ambivalent, with setbacks in certain areas and progress in others. What is different now compared to the preCrimea period is that Russia's room for manoeuvre is more circumscribed, and the need for a flourishing relationship with its Eastern partner has thus become more pressing.

At the regional level we can note certain progress in Russian-Chinese coordination, as regards both security and the economic aspects. The 2013 Russian-Chinese-Bruneian initiative for a new security architecture, which initially appeared to have low priority, ${ }^{3}$ has been followed up with five rounds of East Asia Summit meetings. Specifically, Russia and China have, according to Lavrov, agreed to coordinate more closely their 'efforts to advance the initiative for forming a modern security architecture in the Asia-Pacific region' (Ministry of Foreign Affairs 2015). Furthermore, joint military exercises continue to be organized. In particular, the joint naval exercises appear to have become important for bilateral RussianChinese military relations. These exercises have been held on a larger scale and include more vessels than in previous years. In 2015, the initial phase of the joint naval exercise was for the first time held in the Mediterranean (Selishchev and Reshetnikov 2016; TASS 2016).

There have also been concerted efforts concerning the dual task of developing the Russian Far East and integrating the region into AsiaPacific economic networks. In 2015, the first Eastern Economic Forum was held in Vladivostok, with the second being held the year after and the third planned for autumn 2017. The forum is attended by high-level political figures as well as business leaders (participants at the second forum included President Putin, Korean President Park Geun-hye and Japanese Prime Minster Abe). As discussed in Helge Blakkisrud's chapter (Chap. 2), various mechanisms have also been established for attracting foreign investment (most importantly the ASEZs and the Free Port of Vladivostok). These measures indicate that the Russian authorities have taken steps 
towards overcoming the insecurities associated with regional economic integration of the Russian Far East in the wider Asia-Pacific region.

Politically, fears of Chinese influence have not disappeared. Russia is wary of losing autonomy in its foreign policy. A voice close to the Kremlin cautions that, while China has been an important source of support between 2014 and 2016 'making it easier for Russia to uphold its interests', 'with this paradigm still in existence, Russia will never be able to take decisions interfering with the Chinese interests' (Bordachev 2017). The answer is diversification. If Russia is serious about wanting to broaden its circle of Asia-Pacific partners, this could facilitate rapprochement with Japan. One unexpected outcome of the post-Crimea security developments is the continued improvement in relations between Russia and Japan. To some extent, this improvement is the result of a longer-term attempt to reinvigorate ties, but it also reflects Tokyo's concerns regarding the burgeoning Russo-Chinese ties in the Asia-Pacific. Given the overall intractability of the Kuril Island dispute over the past decades, any swift resolution of the territorial issue is unlikely. However, Japan's interests are pragmatic in nature, focused to a large extent on energy. While this focus on energy security may help in defusing territorial tensions, it nevertheless entails its own challenges: 'basing Japan-Russia ties primarily on energy runs the risk that the bilateral relationship will become a prisoner to market forces, such as fluctuations in oil price' (Rinna 2016).

\section{Conclusions}

Examining Russia's security policy in the Far Eastern region necessitates a broad approach. As this chapter has shown, there have been several key initiatives in the military sphere and in international relations that matter for the Kremlin's security policy. The strategic partnership with China remains central, also against the background of intensified Russian diplomacy towards Japan: in the context of the overall deterioration in relations with the West, attempts to diversify relations remain difficult. At the same time, some actors - notably Japan-have moved to take advantage of Russia's limited range of options in the economic sphere resulting from its current financial isolation, hereunder concluding new energy agreements. Such agreements do not, however, have the capacity to transform Russia from being a bystander in the Asia-Pacific region nor will they, without a concerted push from the Russian federal authorities to improve investor confidence, boost the development of the Russian Far East. 
However, it is important to keep in mind that Russian policy documents and statements clearly identify the underdevelopment of the Russian Far East as a threat to national security. For all the official statements on the primacy of the Russo-Chinese strategic partnership or the growing centrality of the Asia-Pacific region in world affairs, security concerns related to the social and economic underdevelopment of the Russian Far East have delayed any grounding of the 'pivot' in broad regional engagement. The asymmetry between Russia's underdeveloped Far Eastern region and the populous and economically thriving countries of the AsiaPacific region is recognized as a significant vulnerability for Russia. This leads to the securitization of policies aimed at developing the Russian Far East, integration of Russia into the Asia-Pacific region and a deepening of Russo-Chinese relations.

It might be argued that the Russian approach to the Russian Far East and Asia-Pacific region are marked by an urgency borne out of longstanding security concerns and the increasing awareness of shifts in global economic power, especially after the financial crisis-and China's One Belt, One Road (OBOR) initiative has, if anything, intensified this urgency. However, the 2014 Ukrainian crisis in itself seems to have caused only limited concrete changes; as we have seen, the drivers behind Moscow's various post-2014 activities towards the Russian Far East and the AsiaPacific region were present already before the 2014 crisis. The major difference lies in the intensified political and diplomatic attention to bilateral relations with China, although this may be more rhetorical than substantial. Moreover, Russia's deteriorating relations with the West also challenge the Sino-Russian bilateral relationship: China generally seeks cooperative relations ('a harmonious world') across the board, whereas for both countries, relations with the West remain a higher priority than relations with each other.

Nevertheless, the real challenge to the strategic partnership lies not at the international level, but at the regional and local levels. The Russian Far East has always relied on massive assistance from the federal authorities. Now that this is cut back due to current economic constraints, the need for foreign investment has become more pressing than ever. The only real investor remains China, and that underlines the longer-term dilemma for Russia: Chinese investment is seen as part and parcel of Chinese economic hegemony not only here but also in Central Asia and further afield, and thus as a major security concern. In 2015, the Heilongjiang Land and Maritime Silk Road Economic Belt, incorporating the Russian Far East, 
was included in the China-Mongolia-Russia Economic Corridor (Xuefei and Mengxing 2015). Thus, when the OBOR with its Silk Road Economic Belt in Central Asia and the Maritime Silk Road in Asia-Pacific is rolled out in a Chinese grand strategy initiative, both exclusion and inclusion from the OBOR may mean peripheral status for the Russian Far East-as part of a declining Russia, or in relation to a greater China.

\section{Notes}

1. Data retrieved from the Federal State Statistic Service's migration data available at http://www.gks.ru/bgd/regl/bl1_107 (2010); http://www.gks. ru/bgd/regl/bl2_107 (2011) and http://www.gks.ru/bgd/regl/bl3_107 (2012). Data on net numbers are not available for the period 2009-13.

2. The Kuril Islands/Northern Territories are located southwest of the Russian Kamchatka Peninsula. The dispute has long historical antecedents; its current iteration stems from Soviet claims to administrative control over the southern Kuril Islands following the Second World War.

3. President Putin was one of few state leaders absent at the summit when Russia had launched this initiative.

\section{REFERENCES}

Akaha, Tsuneo. 2012. 'A distant neighbor: Russia's search to find its place in East Asia', Global Asia 7(2): 1-14.

Baev, Pavel. 2016. 'Russia's pivot to China goes astray: the impact on the AsiaPacific security architecture', Contemporary Security Policy 37(1): 89-110.

Blank, Stephen. 2014. 'Russia and Japan: can two-plus-two equal more than four?' East Asia Bulletin, 251. http://scholarspace.manoa.hawaii.edu/bitstream/ 10125/32714/1/APB\%20no.\%20251.pdf. Accessed on 15 February 2017.

Bolt, Paul J. and Sharyl Cross. 2010. 'The contemporary Sino-Russian strategic partnership: challenges and opportunities for the twenty-first century', Asian Security 6(3): 191-213.

Bordachev, Timofei. 2017. 'To Russia's friends in Asia and beyond', Valdai Discussion Club, 15 February. http://valdaiclub.com/a/highlights/to-russiafriends-in-asia-and-beyond. Accessed on 30 June 2017.

Carlsson, Märta, Johan Norberg and Fredrik Westerlund. 2013. 'The military capability of Russia's armed forces in 2013', in Russian military capability in a ten-year perspective - 2013, edited by Jakob Hedenskog and Carolina Vendil Pallin, 23-70. Stockholm: FOI. 
Chotani, Vindu Mai. 2015. 'Can Japan and Russia resolve their territorial dispute?' The Diplomat, 5 October. http://thediplomat.com/2015/10/can-japan-andrussia-resolve-their-territorial-dispute. Accessed on 15 January 2017.

Connolly, Richard. 2016. 'The empire strikes back: economic statecraft and the securitisation of political economy in Russia', Europe-Asia Studies 68(4): 750-73.

Cooper, Julian. 2016. Russia's state armament programme to 2020: a quantitative assessment of implementation 2011-2015. Stockholm: FOI.

Fortescue, Stephen. 2016. 'Russia's “turn to the east”: a study in policy making', Post-Soviet Affairs 32(5): 423-54.

Friedberg, Aaron L. 2015. 'The debate over US China strategy', Survival 57(3): 89-110.

Gabuev, Alexander. 2015. 'A soft alliance? Russia-China relations after Ukraine', European Council on Foreign Relations Policy Brief, 10 February. http://www. ecfr.eu/publications/summary/a_soft_alliance_russia_china_relations_after_ the_ukraine_crisis331. Accessed on 28 June 2017.

Gelb, Leslie H. and Dimitri K. Simes. 2013. 'Beware Collusion of China, Russia', The National Interest, July/August. http://nationalinterest.org/article/ beware-collusion-china-russia-8640. Accessed on 26 October 2017.

Goldstein, Lyle. 2017. 'A China-Russia alliance?', The National Interest, 25 April. http://nationalinterest.org/feature/china-russia-alliance-20333. Accessed on 29 June 2017.

Green, Mike. 2016. 'The legacy of Obama's 'pivot' to Asia', Foreign Policy, 3 September. http://foreignpolicy.com/2016/09/03/the-legacy-of-obamaspivot-to-asia. Accessed on 15 December 2016.

Hyodo, Shinji. 2014. 'Russia's security policy towards East Asia', in Russia and East Asia: informal and gradual integration, edited by Tsuneo Akaha and Anna Vassilieva, 44-55. London: Routledge.

Karaganov, Sergei. 2012. K velikomu okeanu, ili novaia globalizatsiia Rossii [ To the great ocean, or the new globalization of Russia]. Moscow: Valdai Club/RIA Novosti.

Karaganov, Sergei. 2014. 'Strategiia XXI: Povorot na Vostok' [Strategy 21: the pivot to the east], 28 January. http://www.vedomosti.ru/newspaper/articles/2014/01/28/povorot-na-vostok. Accessed on 10 January 2017.

Kireeva, Anna. 2014. 'Regional strategies and military buildup in East Asia and Indo-Pacific: a Russian perspective', Maritime Affairs 10(2): 33-51.

Koldunova, Ekaterina. 2016. 'Russia's involvement in regional cooperation in East Asia', Asian Survey 56(3): 532-54.

Kremlin.ru. 2013. 'Soveshanie po voprosam sotsial'no-ekonomicheskogo razvitiia Primor'ia' [Meeting on the socioeconomic development of Primorye], 31 August. http://www.kremlin.ru/events/president/news/19112. Accessed on 21 January 2017. 
Kremlin.ru. 2016a. 'Interview to the Xinhua News Agency of China', 23 June. http://en.kremlin.ru/events/president/news/52204. Accessed on 27 December 2016.

Kremlin.ru. 2016b. 'Meeting with Chairman of the Standing Committee of the National People's Congress Zhang Dejiang', 25 June. http://en.kremlin.ru/ events/president/news/52267. Accessed on 28 December 2016

Kuhrt, Natasha. 2007. Russian policy towards China and Japan: the El'tsin and Putin periods. London: Routledge.

Kuhrt, Natasha. 2012. 'The Russian Far East in Russia's Asia policy: dual integration or double periphery?' Europe-Asia Studies 64(3): 471-93.

Kuhrt, Natasha. 2014. 'Russia and Asia-Pacific: from "competing" to "complementary" regionalisms?' Politics 34(2): 138-48.

Larin, Aleksandr. 2008. Kitai $i$ zarubezhnye kitaitsy [China and the Chinese abroad]. Moscow: RAN, Institut Dal'nego Vostoka.

Larin, Victor. 2012. 'Perceptions of Chinese migrants in the Russian Far East', in Chinese Migrants in Russia, Central Asia and Eastern Europe, edited by Felix B. Chang and Sunnie T. Rucker-Chang, 69-83. London: Routledge.

Lenta.ru. 2015. 'Strashnaia skazka' [A scary fairy tale], 24 November. https:// lenta.ru/articles/2015/11/24/mythsaboutchinese. Accessed on 27 December 2017.

Lo, Bobo. 2008. Axis of convenience: Moscow, Beijing, and the new geopolitics. London: Chatham House.

Lukianov, Fedor. 2010. 'Povorot na vostok' [The turn to the East], SVOP, 15 February. http://old.svop.ru/mm/2010/mm25.htm. Accessed on 10 January 2017.

Lukin, Artyom. 2012. 'Russia and America in the Asia-Pacific: a new entente?' Asian Politics \& Policy 4(2): 153-71.

Ministry of Foreign Affairs. 2013. Concept of the Foreign Policy of the Russian Federation. http://www.mid.ru/en/foreign_policy/official_documents/-/ asset_publisher/CptICkB6BZ29/content/id/122186?p_p_id=101_ INSTANCE_CptICkB6BZ29\&_101_INSTANCE_CptICkB6BZ29_ languageId=en_GB. Accessed on 7 December 2016.

Ministry of Foreign Affairs. 2014. 'Interview of the Russian Foreign Minister Sergey Lavrov to China Daily', 15 April. http://www.mid.ru/en/foreign_policy/news/-/asset_publisher/cKNonkJE02Bw/content/id/65422. Accessed on 17 March 2017.

Ministry of Foreign Affairs. 2015. 'Foreign Minister Sergey Lavrov's opening remarks and answers to media questions at a joint news conference following a meeting of the foreign ministers of Russia, India and China (RIC)', 2 February. http://www.mid.ru/en/foreign_policy/news/-_asset_publisher/cKNon$\mathrm{kJE} 02 \mathrm{Bw} /$ content/id/947158. Accessed on 15 January 2017. 
Ministry of Foreign Affairs. 2016. Foreign Policy Concept of the Russian Federation. http://www.mid.ru/foreign_policy/news/-/asset_publisher/cKNonkJE02Bw/content/id/2542248. Accessed on 12 March 2017.

Pajon, Céline. 2013. 'Japan-Russia: toward a strategic partnership?' Russie.nei. visions 72. Paris: IFRI.

Permanent Mission of the People's Republic of China to the UN. 2016. 'Statement by Ambassador Liu Jieyi at the Security Council after voting on the draft resolutions on Syria', 8 October. http://www.china-un.org/eng/hyyfy/tl405969. htm. Accessed on 28 December 2016.

Plopsky, Guy. 2016. 'How Russia is bolstering missile defense in its Far East', The Diplomat, 2 August. http://thediplomat.com/2016/08/how-russia-is-bolstering-missile-defense-in-its-far-east. Accessed on 16 November 2016.

Pravitel'stvo Rossiiskoi Federatsii. 2013. Federal'naia tselevaia programma 'Ekonomicheskaia $i$ sotsial'naia razvitiia Dal'nego Vostoka i Baikal'skogo regiona na period do 2018 goda' [Federal targeted programme 'Economic and Social Development of the Far East and Baikal Region until 2018']. http://assoc.khv. gov.ru/files/docs/2015/0e1559ec080b88029c99.pdf. Accessed on 20 December 2016.

Pulin, Gennadii. 2005. 'Smysly i podteksty "Mirnoi missii-2005"' [The meanings and implications of 'Peace Mission-2005], Voenno-promyshlennyi kur'er, 31 August. http://vpk-news.ru/articles/56. Accessed on 19 December 2016.

RIA Novosti. 2011. 'Tretii polk S-400 budet razmeshchen na Dal'nem Vostoke' [The third S-400 regiment will be deployed in the Far East], 18 February. https://ria.ru/defense_safety/20110218/335524995.html. Accessed on 19 November 2016.

RIA Novosti. 2015a. 'Voennye vo Vladivostoke nachali osvaivat' S-400 "Triumf"' [The military in Vladivostok began to work with S-400 'Triumph'], 25 November. https://ria.ru/defense_safety/20151125/1327872970.html. Accessed on 10 November 2016.

RIA Novosti. 2015b. 'Priamure i KNR: avtomost, kanatnaia doroga i eksport sladostei' [Amur and China: auto-bridge, cable line and export of sweets], 24 December. https://ria.ru/east/20151224/1347999399.html. Accessed on 14 March 2017.

RIA Novosti. 2016. 'Pervoe uchenie na novykh kompleksakh 'Iskander-M' startovalo v Buriatii' [The first exercise with the new Iskander-M complex began in Buriatia],29February.https://ria.ru/defense_safety/20160229/1381755471. html. Accessed on 10 November 2016.

Rinna, Anthony. 2016. 'Japan-Russia relations need more than just energy', East Asia Forum, 27 May. http://www.eastasiaforum.org/2016/05/27/japanrussia-relations-need-more-than-just-energy. Accessed on 7 February 2017.

Rossiiskaia gazeta. 2009. 'Ukaz Prezidenta Rossiiskoi Federatsii ot 12 maia 2009 g. N 537 “O Strategii natsional'noi bezopasnosti Rossiiskoi Federatsii do 2020 
goda"' [Decree of the President of the Russian Federation of 12 May 2009, N 537 'On the National Security Strategy of the Russian Federation until 2020'], 19 May. https://rg.ru/2009/05/19/strategia-dok.html. Accessed on 30 June 2017.

Selishchev, Aleksei and Dmitrii Reshetnikov. 2016. 'Voenno-morskie uchenia RF i Kitaia nachinaiutsia v Iuzhno-Kitaiskom more' [Naval exercises of Russia and China to begin in the South China Sea], TASS, 12 September. http://tass.ru/ armiya-i-opk/3612999. Accessed on 16 December 2016.

Shestakov, Evgenii. 2013. 'Stanet li Rossiia liderom v Azii?' [Will Russia become a leader in Asia?], Rossiiskaia gazeta, 11 October. https://rg.ru/2013/10/11/ atr-site.html. Accessed on 15 January 2017.

Shin, Beom-Shik. 2014. 'Post-Cold War Russian foreign policy and the Korean Peninsula', in Russia and East Asia: informal and gradual integration, edited by Tsuneo Akaha and Anna Vassilieva, 130-53. London: Routledge.

Silove, Nina. 2016. 'The pivot before the pivot: U.S. strategy to preserve the power balance in Asia', International Security 40(4): 45-88.

Snetkov, Aglaya and Marc Lanteigne. 2015. "The loud dissenter and its cautious partner" - Russia, China, global governance and humanitarian intervention', International Relations of the Asia-Pacific 15(1): 113-46.

Stokes, Jacob. 2017. 'Russia and China's enduring alliance', Foreign Affairs, 22 February. https://www.foreignaffairs.com/articles/china/2017-02-22/russia-and-china-s-enduring-alliance. Accessed on 28 June 2017.

Tabata, Shinichiro. 2012. 'The booming Russo-Japanese economic relations: causes and prospects', Eurasian Geography and Economics, 53(4): 422-41.

TASS. 2016. 'Rossiisko-kitaiskie uchenia "Morskoe vzaimodeistvie". Dos'e' [Russian-Chinese exercises 'Naval interaction': Dossier], 12 September. http://tass.ru/info/1960969. Accessed on 16 December 2016.

United Nations. 2016. 'Security Council fails to adopt two draft resolutions on Syria, despite appeals for action preventing impending humanitarian catastrophe in Aleppo', Meetings coverage and Press Releases, 8 October. https://www. un.org/press/en/2016/sc12545.doc.htm. Accessed on 13 January 2017.

Weitz, Richard. 2012. 'Superpower symbiosis: the Russia-China axis', World Affairs, November/December. http://www.worldaffairsjournal.org/article/ superpower-symbiosis-russia-china-axis. Accessed on 12 March 2017.

Weitz, Richard. 2015. 'Parsing Chinese-Russian military exercise', The Letort Papers. Carlisle, PA: US Army War College.

Wishnick, Elizabeth. 2017. 'In search of the "Other" in Asia: Russia-China relations revisited', The Pacific Review 30(1): 114-32.

Xiang, Lanxin. 2012. 'China and the "pivot"', Survival 54(5): 113-28.

Xuefei, Tian and Song Mengxing. 2015. 'Economic belt work gets underway', China Daily, 17 April. http://www.chinadaily.com.cn/cndy/2015-04/17/ content_20453422.htm. Accessed on 28 June 2017. 
Open Access This chapter is licensed under the terms of the Creative Commons Attribution 4.0 International License (http://creativecommons.org/licenses/ by $/ 4.0 /$ ), which permits use, sharing, adaptation, distribution and reproduction in any medium or format, as long as you give appropriate credit to the original author(s) and the source, provide a link to the Creative Commons license and indicate if changes were made.

The images or other third party material in this book are included in the book's Creative Commons license, unless indicated otherwise in a credit line to the material. If material is not included in the book's Creative Commons license and your intended use is not permitted by statutory regulation or exceeds the permitted use, you will need to obtain permission directly from the copyright holder. 